\title{
Triangulating consumers' perceptions of payment systems using social representations theory: A multi-method approach
}

\author{
Elfriede Penz • Rudolf R. Sinkovics
}

\section{This is a pre-print (non-publisher's document). Please cite the published article:}

Penz, Elfriede and Rudolf R. Sinkovics (2013), "Triangulating consumers' perceptions of payment systems by using social representations theory: A multi-method approach," Journal of Consumer Behaviour, 12 (4), 293-306. (DOI: 10.1002/cb.1420).

\section{Abstract and Key Results}

- Social systems play a pivotal role in shaping customers' views, the adoption process and subsequent product diffusion for novel products. Perceptions of Austrian consumers regarding payment systems were assessed in a cross-sectional analysis applying social representations theory. Social representations help to unravel the sources of individuals' attitudinal or perceptual similarities and differences, which often stem from inter-group differences. In short, they are useful for the investigation of "deeper structure" aspects of consumer behaviour, as has been shown in previous studies (e.g, Penz and Stöttinger, 2008; Roland-Lévy, Boumelki, and Guillet, 2010; Stewart and Lacassagne, 2005). This may be seen as a further step forward for marketing research, which operates largely on social phenomena.

- This study addresses the shortage of non-cognitive based research in marketing by offering a methodological approach that uses triangulation based on associative answers from social groups. A four-step analytic design revealed that consumer groups transpose the abstract concept of payment systems into tangible objects and processes in a similar way, however, their social background impacted which value was attached to established as well as new means of payment. Cash is still seen as the prototypical form of payment; newer forms, such as credit-cards or ATM cards appear already in the periphery of representations, urgently needing well-concerted marketing efforts to become recognized as substitutes for cash. From a managerial view, the research employs social phenomena as a basis for segmenting natural rather than nominal groups in order to better serve consumers' needs in an increasingly connected social reality.

\section{Key Words}

Social representations; financial products; innovation; social phenomena 


\section{Authors}

Elfriede Penz $(\square)$

Associate Professor of International Marketing

Vienna University of Economics and Business

Augasse 2-6, A-1090 Vienna, Austria.

Elfriede.Penz@wu.ac.at

Rudolf R. Sinkovics

Professor of International Business

Centre for Comparative and International Business Research

The University of Manchester, Manchester Business School

Booth Street West, Manchester M15 6PB, UK.

Rudolf.Sinkovics@manchester.ac.uk

www.manchester.ac.uk/research/rudolf.sinkovics 


\title{
Triangulating consumers' perceptions of payment systems using social representations theory: A multi-method approach
}

\begin{abstract}
Social systems play a pivotal role in shaping customers' views, the adoption process and subsequent product diffusion for novel products. Perceptions of Austrian consumers regarding payment systems were assessed in a cross-sectional analysis applying social representations theory. Social representations help to unravel the sources of individuals' attitudinal or perceptual similarities and differences, which often stem from inter-group differences. In short, they are useful for the investigation of "deeper structure" aspects of consumer behaviour, as has been shown in previous studies (e.g, Penz and Stöttinger, 2008; RolandLévy, Boumelki, and Guillet, 2010; Stewart and Lacassagne, 2005). This may be seen as a further step forward for marketing research, which operates largely on social phenomena.

This study addresses the shortage of non-cognitive based research in marketing by offering a methodological approach that uses triangulation based on associative answers from social groups. A four-step analytic design revealed that consumer groups transpose the abstract concept of payment systems into tangible objects and processes in a similar way, however, their social background impacted which value was attached to established as well as new means of payment. Cash is still seen as the prototypical form of payment; newer forms, such as credit-cards or ATM cards appear already in the periphery of representations, urgently needing well-concerted marketing efforts to become recognized as substitutes for cash. From a managerial view, the research employs social phenomena as a basis for segmenting natural rather than nominal groups in order to better serve consumers' needs in an increasingly connected social reality.
\end{abstract}

KEYWORDS: Social representations; financial products; innovation; social phenomena 


\section{Triangulating consumers' perceptions of payment systems using social representations theory: A multi-method approach}

\section{INTRODUCTION}

Consumers often find it difficult to position innovations into a framework that they can comprehend. Financial innovations such as new forms of payment affect consumers' everyday experiences in an increasingly digital marketplace, and thus are noteworthy to study. In Europe, electronic ways of money transfer or electronic payment systems (Abrazhevich, 2001), such as the electronic purse (card-based system) or internet banking (account-based system) have been introduced to replace cash transactions. Despite great efforts from banking institutions (Bednar, Reeves, and Lawrence, 1995) to redress the meaning of money (Belk and Wallendorf, 1990), the adoption of more advanced or innovative electronic payment systems is still lagging behind banking institutions' and merchants' expectations.

Electronic payment systems can serve as an extreme example of how social interactions define the functionality of service. On the one side, customers have to trust electronic forms of payment and use these. On the other side, intermediaries (merchants or other banks) have to supply hardware and distribution channels to provide benefits to customers (Molesworth and Suortfi, 2002; O'Loughlin and Szmigin, 2006; Plouffe, Vandenbosch, and Hulland, 2001). If one side fails to adopt the innovation, the diffusion is slowed or halted. This reliance on social interactions for new product diffusion can be seen as network externality (e.g., Timmor and Katz-Navon, 2008; Wang, Lo, and Fang, 2008), which is defined as the fact that "the utility that a user derives from consumption of the good increases with the number of other agents consuming the good." (Liebowitz and Margolis, 1994, p. 133). The benefit consumers derive from the use of a product and the decision to adopt this product depend greatly on 
consumers' social environment and on the number of other consumers using compatible items (Katz and Shapiro, 1986; Timmor and Katz-Navon, 2008).

We follow the call for new, non-cognitive based research in marketing that has increasingly appeared. For example, emotions are considered to be as important as cognitions in explaining consumption, and thus have been progressively included in consumer research (Bagozzi, Gopinath, and Nyer, 1999; Holbrook and Hirschman, 1982; Leone, Perugini, and Bagozzi, 2005). Also, postmodern consumer culture theories emerged stressing symbolic meanings of products as means to construct identity and define social reality (Elliott, 1999). Consumers with a common life view form networks of societal micro groups (Cova, 1997; Cova and Cova, 2002; Featherstone, 1991). These groupings happen through shared beliefs, emotions, lifestyles, and consumption practices, enabling consumers to deal with the fuzziness and heterogeneity of today's markets and postmodern consumer cultures (Elliott, 1999).

In general, a receptivity towards sociological, anthropological and cultural perspectives in marketing (Nataraajan and Bagozzi, 1999) is suggested to capture the complex reality of social exchange. As a suitable research paradigm (Elliott, 1999), the social representations theory is used in this research to triangulate consumers' perceptions of payment systems ${ }^{1}$. This helps to identify the positioning of new versus traditional payment forms, especially those that are influenced by network effects (e.g., Timmor and Katz-Navon, 2008; Wang et al., 2008).

The aim of this study is to provide a methodology that is capable of capturing social exchange, and the collective construction of social reality in order to understand consumers' perceptions of payment systems. This paper contributes to existing, mainly cognition-based literature of product innovations by studying consumers' social representations of payment

\footnotetext{
${ }^{1}$ A payment system is defined as a "financial system supporting transfer of funds from suppliers (savers) to the users (borrowers), and from payers to the payees, usually through exchange of debits and credits among financial institutions." (http://www.businessdictionary.com/definition/payment-system.html\#ixzz29RuOVi6I).
} 
systems by means of triangulation. While significant theoretical advancements have been made in the area of product innovation (Rogers, 1995) and, for instance, the technology acceptance model (TAM, e.g., Davis, Bagozzi, and Warshaw, 1989) has been applied to explain product adoption (e.g., Wang et al., 2008), we argue that "traditional" attitudinal measurement techniques and the application of multivariate clustering procedures might be insufficient (Gatignon and Robertson, 1991). Attitudinal measurement is based on methodological individualism and on an epistemology, which functionally separates the subject who is being measured from the object of measurement (Farr, 1996). This separation poses a distinct problem for research. It implies that the group context, within which the evaluations of objects or products will take place, is left untouched and important information is lost due to the focus on individuals. Even considering that attitudinal measurement may involve responses from a number of people, the theoretical disadvantage persists. The grouplevel is not captured in the measurement process, but solely the individual level.

The diffusion of the electronic payment system in a European country is used as the context for this research. Within the last couple of years the meaning of money has made a significant shift. What has always been considered a volatile concept, has become even more intangible and fragmented due to further advancements in information and communication technology, e-commerce and electronic forms of payment (e.g., Abrazhevich, 2001; Furnham and Argyle, 1998; O'Loughlin and Szmigin, 2006; Penz et al., 2004).

In the next section the conceptual background is presented. Individual and socialpsychological views, i.e., attitudes and social representations are contrasted and measurement issues of social representations addressed. The methodology section subsequently exemplifies reasoning in the context of an empirical study and measurement issues are brought forward. 


\section{CONCEPTUAL BACKGROUND}

\section{Consumers' knowledge structures of innovations}

How consumers organize their knowledge about and associations between concepts has been studied within the associative network structure model (e.g., Joiner, 1998; Lawson, 2002) or within socio-cognitive conceptualization (Rosa, Porac, Runser-Spanjol, and Saxon, 1999). Influences of consumers' knowledge on their information-processing (Alba and Hutchinson, 1987), and product evaluations (Blair and Innis, 1996; Cordell, 1997), has been investigated, as well as the influence on consumers' responses to marketing activities (e.g., Buchanan-Oliver, Cruz, and Schroeder, 2010; Roy and Cornwell, 2004). The underlying idea is that consumers' knowledge structures (e.g., brands, products, and situations) are nodes in memory to which associations are linked (Joiner, 1998).

With respect to new product introductions, the analogical learning theory (GreganPaxton and John, 1997; Gregan-Paxton and Moreau, 2003) served as the theoretical basis to understand how prior knowledge influences consumers' perceptions of really new products (Gregan-Paxton, Hibbard, Brunel, and Azar, 2002). Analogical learning theory posits that knowledge from one area is transferred to another based on their correspondence (GreganPaxton and John, 1997). The authors argue that consumer reasoning about a really new product is a problem of identifying the appropriate representation of the product. In this respect, they use the term "good" representation for a situation in which a framework for interpreting the new product is provided. In the financial context, for example, the concept electronic purse includes a learned component (purse for cash) that consumers are familiar with and a new one (electronic transfer of money). Offering the right framework enables consumer problem-solving and comprehension. Expertise indicates not only more knowledge, but also more richly interconnected knowledge (Gregan-Paxton et al., 2002). 
However, it is argued that viewing the individual as an isolated information processor represents a somewhat limited view of cognition (Forgas, 1981; Morgan and Schwalbe, 1990). More emphasis needs to be put on norms (Jansson, Marell, and Nordlund, 2011) and on the social context in which such information processing takes place (Nataraajan and Bagozzi, 1999). Social cognition takes into consideration that cognition is a social and not an individual activity. Knowledge arises from the interaction between information processing strategies, and socio-cultural processes and, therefore, cognition cannot be properly understood without studying society and culture as the product of the cognitive efforts of individuals. Also, higher mental activities, such as language, reasoning and representations can only be studied in their proper socio-cultural context (Forgas, 1981). Social cognition should, therefore, include more than purely cognitive phenomena in order to explain social action (e.g., values, motives; Forgas, 1981).

\section{Social representations theory}

Social representations theory, which was introduced by Moscovici $(1961,1963)$, builds on existing, socially shared and constructed knowledge or 'common sense perspectives' about familiar products that can easily be associated with new products. Consumers, who build their product evaluations on comparisons with their social group, will activate and adjust existing knowledge against new knowledge about the innovation (see also Timmor and Katz-Navon, 2008). Exposure to media and interactions with relevant others creates consumer perceptions that can be positioned within a familiar framework (e.g., Gaskell and Smith, 1985). Especially when faced with new economic or societal developments, people wish to assess, evaluate and compare their perceptions with others. This view is also consistent with the perspective that customers receive benefits from community participation (Bagozzi and Dholakia, 2006; Bhattacharya and Sankar, 2003; Timmor and Katz-Navon, 2008). In this context, the theory of social representations fits to the idea of social exchange in marketing, which encompasses the concept of a balance between "individual, dyadic, and larger social needs" (Nataraajan 
and Bagozzi, 1999, p. 640). Moscovici's theory is suitable to unravel structures from consumers, which otherwise remain untouched. Within the context of the social representations theory, the focus of investigation is on the social context in which consumers learn, perceive and develop their views, rather than on individual attitudinal dimensions. Social representations theory is conceptually very rich and suitable for capturing views about products, which a group shares. Especially in view of technological innovations, such as new payment innovations ${ }^{2}$, the theory of social representations is able to overcome limitations of individual-level feedback.

Social representations are created out of new knowledge and ideas, which are integrated into already existing representations by means of anchoring and objectification (Abric, 1996b; Moscovici, 1984; Roland-Lévy, 2001). Anchoring is the process by which new knowledge, ideas, etc. are adopted by a social group, required there is a fit with already existing categorization schemes. If new knowledge, an idea etc. fits the existing categorization scheme, it will be integrated and henceforth update the underlying categorization scheme. Objectification refers to the process by which abstract ideas or concepts become a concrete form, either as an object (in the context of this study, the creditcard is considered as a symbol of wealth) or a picture (e.g., Scrooge McDuck caressing banknotes and coins). The more linkages social groups can establish between new ideas and existing knowledge, the higher the probability of these new ideas becoming part of social representations. In this respect, social representations theory can be compared to the analogical learning theory, which showed that consumers' understanding of really new products is facilitated by the use of analogies. "Analogy emphasizes key features in a new domain and, at a more abstract level, provides a structure capable of organizing the constellation of features comprising an unfamiliar domain" (Gregan-Paxton et al., 2002, p.

\footnotetext{
2 According to Kleinschmidt (1991) innovations in the financial industry represent rather incremental changes than
} radical technological innovations (see also Gatignon and Robertson, 1991). 
545). Social representations theory extends this view by focusing on the collective elaboration of objects or products and on the outcomes of "talk and actions" (Wagner et al., 1999), as related to socio-group perspectives.

Social representations consist of elements that are organized (Abric, 1996a, 1996b). Two different types of elements of social representations are distinguished: First, central elements form the nucleus of a social group's social representations. The nucleus aims at organizing the social group's ideas, generating meanings for the ideas, and operates as a normative constraint for the social group. The nucleus is assumed to be rather stable over time and changes less quickly than peripheral elements. Peripheral elements, on the other hand, may change due to individual reasons and thus protect the nucleus (for a discussion of change in social representations see for example, Abric, 1993).

\section{Measurement issues of social representations}

The social representations theory has been used in connection with a vast variety of methods, impressing with methodological variety and freedom (de Rosa, 1994; Rateau, Moliner, Guimelli, and Abric, 2012). The methods used range from anthropologically oriented methods, such as ethnography, to descriptive investigations of group consensus (e.g., Fraser, 1994), qualitative text analysis (e.g., Melina, 1998; Roland-Lévy, 1990) to the use of surveys and experimental designs (e.g., Bauer and Gaskell, 1999; Flick, 1996; Kirchler, Maciejovsky, and Schneider, 2003; Wagner et al., 1999), the application of multivariate statistical procedures (e.g., Doise, Clemence, and Lorenzi-Cioldi, 1993), or the use of the associative network (Meier and Kirchler, 1998; Penz et al., 2004). Procedures for data collection within a social representations perspective are suggested for comparing norms and values associated with a particular social object in different social or cultural groups (Stewart and Lacassagne, 2005) or to explore representatives of a certain culture and their thinking about objects, products and their associations (Penz, 2006). 
Bauer and Gaskell (1999) developed different strategies to study social representations and integrated them in a framework. These strategies can be seen as a typology of possible alternative research avenues to work on social representations. The framework consists of the analysis of the content and the process of social representations. Studying images, metaphors and free associations allows the assessment of the function (anchoring, objectification) and the organization (central nucleus and periphery) of social representations for a social group.

It involves the selection of a social group for analysis. The study of social representations requires the specification of appropriate social segments, which on top of the aforementioned characteristics have a shared history, world view or are exposed collectively to mass media. In addition to established ways of market segmentation, social milieus produce groupings which are self-referential (e.g., people who adopted IT easily call themselves the "Internet-generation") and share a collective memory (e.g., the knowledge about the rise of IT or memory about the times without PC's). Thus, events in the past influence the meaning of social objects, such as money (Wagner et al., 1999). Introducing the Euro as a community currency serves as a good example for shared history. Those who have witnessed the event have formed a collective memory, which includes the former national currency as well as the new currency. Another social grouping appears in the formation of sex roles. The roles women and men display are considered to be influenced by the social context (Eagly, 1987; Meier-Pesti and Penz, 2008; Mühlbacher, Hofmann, Kirchler, and RolandLévy, 2009).

The framework also involves the cultivation within the social group. This strategy is highly process-oriented and includes both analysis of informal and formal communication relations between a sender and receivers. The sender's perspective on specific social milieus may lead to a plurality of representations of a single issue. For example, the information 
consumer organisations provide, compared to the information banking institutions provide to consumers varies and leads to different social representations.

The analysis of social representations within a defined social group can combine different data sources in a multi-method analysis. According to different research aims, field observations are suggested for behavioural habits, surveys for individual cognitions or document analysis for formal communication (e.g., de Rosa, 1994; Doise, Clemence, and Lorenzi-Cioldi, 1993; Rateau, Moliner, Guimelli, and Abric, 2012). However, this strategy is not restricted to social representations approach and referred to as triangulation (see, e.g., Jick, 1979; Scandura and Williams, 2000).

Using longitudinal data corresponds well with the dynamic nature of social representations (Moscovici, 1984). As Bauer and Gaskell (1999) point out, the "life-cycle of social representations is somewhere between the elusiveness of the flow of consciousness and the 'long duree' of mentalities" (p. 178). By means of comparative and longitudinal analysis, changes in the structure and the functions of social representations due to changes in the socio-economic or political environment can be observed.

The involved parties that cope with threats differently and their diverging coping strategies are yet another focus of analysis.

Finally, a disinterested researcher is called for. Researchers should avoid "social engineering" in empirical enquiry (Bauer and Gaskell, 1999, p. 179) and resist the temptation to virtually create social realities. Figure 1 illustrates the main elements of obtaining the meaning of payment systems through the analysis of social representations.

Insert Figure 1 about here 


\section{METHODOLOGY}

A sample of consumers was analysed in Austria, using a multi-method approach. The research strategies employed follow Bauer and Gaskell's (1999) framework. Individual empirical steps, methodological decisions and their rationale are presented in more detail as follows.

\section{Instrument}

A measurement tool was developed, which comprised of two sections. The first section addressed "associative networks" (de Rosa, 1995) and served as a means to identify "objectifications" and "anchored components" (Abric, 1993) of the payment concept. The second section of the instrument followed the idea of the "conceptual network method" (Vergès, 1996; Vergès and Flament, 1997) and was deemed to measure similarities between economic and social components of everyday interactions, life and the payment concept (content and process of social representations).

We defined social groups for analysis by exploring similarities and differences among groups. This follows Plouffe, Vandenbosch and Hulland (2001), who suggest analysing consumers' perceptions of innovations using multiple groups, and to split the potential market into adopters and non-adopters. The sample consisted of people living in urban and in rural environments because ATM locations, banking branches and shopping outlets demonstrate lower concentration patterns in the latter. Furthermore, urban dwellers are more frequently exposed to various shopping opportunities. These segments share their group-specific common perspectives of daily life and thus dispose of a collective memory. Another characteristic for identification was sex-roles, as females and males are found to differ in their attitudes towards money and their handling of money (Furnham and Argyle, 1998; Prince, 1993). Finally, differences regarding frequency of using plastic money (Jacobson, 1990; 
Nentwich, Peissl, and Pisjak, 1993) were captured by selecting consumers with varying educational backgrounds.

\section{Sample}

A non-probability quota sample was employed (Gilbert, 2008; Iacobucci and Churchill, 2010), which was drawn from the eastern part of Austria. Vienna and nearby counties were involved, providing for a geographical mix of rural, urban and metropolitan areas. A total of 700 questionnaires were distributed by means of a "questionnaire-drop-in" technique by six interviewers, who distributed the questionnaires to potential respondents. The questionnaires were completed by respondents in absence of the interviewer and collected after completion. Employing this sampling procedure helped to save time and costs because questionnaires were filled in autonomously and no postal mailing was necessary (Iacobucci and Churchill, 2010). Out of the 700 distributed questionnaires, 173 useable questionnaires (including responses to all questions) were returned and delivered a response rate of 25 per cent. Due to this particular sampling procedure, non-response bias (Armstrong and Overton, 1977; Lambert and Harrington, 1990) was not applicable and hence not tested for.

The actual sample comprised of 52 per cent males and 47 per cent females, with an average age of 36 years $(\mathrm{SD}=14.38)$. The largest bulk of respondents was in the 20-29 years age band. Almost half of the respondents were single (43 per cent), followed by a large number of individuals who were married (40 per cent). As indicated in the sampling frame, the sample was taken from the population in the eastern part of Austria, with 66 per cent of respondents living in cities, and the rest living in rural areas. However, due to self-selection, the sample cannot be considered as representative, but indicative of social groups who share several characteristics, including social milieus or geographical space. Table 1 provides an overview of the sample characteristics. 
Insert Table 1 about here

\section{Analytic design}

Subsequent to data collection, a multi-method approach to data analysis was pursued (see Table 2). By centring the focus of attention within each methodological procedure on slightly different aspects of the underlying social representations, the analytic design was deemed appropriate to triangulate (see, for example, Jick, 1979; Scandura and Williams, 2000) consumer perspectives on payment systems.

Insert Table 2 about here

The first step in the analytic design (see Table 2) involved free associations, which were elicited from respondents to identify their views regarding payment systems. The term "payment systems" was the stimulus. The instruction read: "When thinking about payment systems, which ideas, pictures or thoughts, etc. are coming to your mind?" This helped to create a list of associations. We opted for this general stimulus rather than specific forms of payment in order to retrieve as many spontaneous reactions in the form of emotions, ideas, and opinions as possible, and to understand if and what forms of electronic payment were included in consumers' mindset. The rationale for this practice was the thinking that by employing the term "payment systems" as a generic and traditional cue we would manage to identify the foundations for this term. In line with suggestions from the literature, this design helped to identify the social content (Abric, 1996a; Moscovici, 1984) of means of payments, and to augment our learning about those dimensions of payment systems, which were solidly rooted in the society. The responses were aggregated, categorized and entered into correspondence analysis.

The second step concerned the analysis of the evaluative dimension of payment systems. Each association was evaluated by the respondents as either positive, negative or neutral and 
indices of polarity and neutrality were calculated (de Rosa, 1995; de Rosa and Kirchler, 2001). The polarity index is the relationship between the difference of positively and negatively evaluated associations and the total number of associations. The polarity index ranges from +1 to -1 , with higher values expressing a positive evaluation of the stimulus term. The neutrality index expresses the relative frequency of neutral associations. Hence, the higher it is, the more neutral the respective stimulus term is evaluated to be.

The third step was based on the same associative network data and employed positional and frequency analysis (Baayen, 2001; Zipf, 1935). An examination of which associations were listed first, second, etc. was conducted. The position at which respondents chose to list their free associations helped to trace for the core and periphery of the payment concepts. Consequently, it helped to identify the configuration of social representations. Those elements that were listed first point to core elements and the others represent peripheral elements. Moscovici (1984) points out that core elements act as relatively stable social norms and peripheral elements are more flexible and can change quickly through out-group influence. For marketers, peripheral elements lend themselves for exploitation in tactical marketing activities. For instance, messages from advertising campaigns including brand names or product attributes (e.g., new features, colours) but also messages from mass media are likely to appear in the periphery of social representations before they become part of their core.

The fourth step in our analytic design served the purpose of linking new to old concepts of payment systems by using the conceptual networks and similarity analysis (Vergès and Bastounis, 2001). The conceptual network is composed of concepts, which were selected based on a literature review and reflect economic (e.g., cash, credit-card, work, savings, taxes) as well as social (e.g., safety, risk, leisure, family) elements of everyday life (Vergès and Bastounis, 2001). This technique is applied to analyse the configuration of social representations, particularly linkages with new payment systems and the connecting socio- 
economic environment. Respondents were asked to link existing dimensions of both payment systems and social/economic concepts by drawing connecting lines. For the purposes of analysis, the number of connected pairs of words was counted and formed into graphs of similarity (Vergès, 1987, 1996; Vergès and Bastounis, 2001). ${ }^{3}$

\section{RESULTS AND DISCUSSION}

The first step within the social representations analysis was based on respondents' free associations regarding the stimulus "payment systems" (content of social representations). We opted to use the rather general stimulus term to find out if and how old and new forms of payment are related. The categorization scheme was based on a thorough review of the relevant literature and feedback from qualitative interviews with five experts in the field of payment systems in Vienna, Austria. The interviews helped us to understand the perspective of banking institutions in respect to financial innovations and to gain insights into payment forms, activities related to means of payment, aspects of the banking world, and financial advantages and disadvantages of different payment forms from a customer perspective. Interviews were content-analyzed and results used as the basis for the categorization scheme. To reduce the large set of qualitative responses, respondents' free associations were categorized into 19 categories $^{4}$ by three independent raters. Inter-rater reliability was satisfactory $($ Cohen's Kappa $=.664)$. An index of stereotypicity was calculated, based on 1.508 associations. 388 associations (i.e., 26\%) were unique, representing different consumerassociations. Hence, the dataset represented highly stereotypical responses with respect to the concept of payment systems.

A similarity index was calculated, using a co-occurrence measure. This measure was favoured against theoretically feasible alternatives such as the phi-coefficient for ordinal data or the Jaccard-index (Degenne, 1985), because it was the aim to identify similarities between variables, in our case the stimulant concepts and terms.

$4 \quad$ Starting off with 37 categories, the number of items and categories were reduced in an iterative process until satisfactory agreement could be achieved among the raters. 19 categories and 1.508 items were retained for subsequent analysis. 
We measured how often the respective categories were mentioned. In order to check for statistically significant group differences, cross-tabulation, and chi-square tests were conducted. The chi-square tests were not significant for each grouping (education: chi-square $=63.03, \mathrm{df}=90, \mathrm{p}=.99$, residence: chi-square $=15.91, \mathrm{df}=18, \mathrm{p}=.60$, gender: chi-square $=$ 11.73, $\mathrm{df}=18, \mathrm{p}=.86$ ), however, calculated standardized residuals indicate some variation between groups. In the following, the variation between groups will be reported. With regard to education, people with a vocational middle school degree put higher emphasis on issues of safety (e.g., low risk, trust) $(\mathrm{z}=2.2, \mathrm{p}<.05)$ compared to other educational groups. People with higher levels of school education favoured the use of terms, which we summarized as general positive expressions (e.g., comfortable, super) $(\mathrm{z}=2.0, \mathrm{p}<.05)$. Finally, people with university or college degrees mentioned terms, which describe characteristics of means of payment (e.g., PIN, signature) $(\mathrm{z}=2.0, \mathrm{p}<.05)$. Individuals did not differ significantly in their associations when urban or rural residency was accounted for. Gender did not account for any differences either. Table 3 shows the descriptions and frequencies of all categories, related chi-square statistics for all groups involved.

Insert Table 3 about here

Applying the method of correspondence analysis to the frequency matrix, associations between response frequencies and certain response groups (education based groups, rural and urban residence and gender) were identified. The correspondence analysis resulted in a twodimensional solution, which explained a total of $54.5 \%$ of variance of the solution (see Figure 2). The overall spatial variation (total inertia) was 0.046 , indicating that the correlation between row points (respondents) and column points (categories) was fairly low. For interpretation of the results, the row and column points which contributed significantly to the two dimensions were taken into consideration (relative contributions higher than 0.1 for row points, and 0.053 for column points) (see Matiaske, Dobrov, and Bronner, 1994). 
Insert Figure 2 about here

The correspondence analysis sheds some light on different facets of payment systems. The first dimension explained $33 \%$ of the variance of the solution and pointed at affective involvement as well as a "descriptive construction of reality", which can be seen as the material representation of the social reality. It comprised positive categories, such as synonymous, positive expressions, freedom but also negative expressions. Respondents with vocational and high school educational backgrounds were equally aligned along dimension one, as were people from urban regions. Categories such as banking world and piece of equipment were configured along the opposite direction of the two-dimensional grid, as well as respondents from rural areas.

The second dimension explained $21.5 \%$ of the variance of the solution and revealed that payment systems are related to dependence as well as independence. Configured along the negative hemisphere of the second dimension were safety/trust issues as well as the fear of loss of money. Respondents with vocational and/or middle school degrees were at the same end of the dimension. On the other hand, the categories currencies, chargelfee, characteristics, but also the categories banking world and piece of equipment represented the positive spectrum of dimension two. These categories describe different payment systems, such as the teller machine, check-books etc. and point at an incremental view of payment systems. Herein, the comprehension of the complex construct "payment systems" is defined via smaller, tangible units, known from day-to-day experiences. Respondents with university degrees frequently shared these perceptions of payment systems.

In all, objectification, as defined by Abric (1996) could be seen in synonyms such as "Kröten, Knete" the German expressions for "Bucks", "Lettuce" (Furnham and Argyle, 1998), which meant that the abstract concept of payment systems was eventually transposed into tangible objects. Freedom, for instance, meant the ability to use the credit card at any 
time, any place. Anchoring, on the other side was represented in the notion of the "banking world". The concept of payment systems corresponded to real-world banking experiences, where consumers saw people involved in the banking and accounting business.

Various indices were calculated to find out how consumers evaluate payment systems. Analyses of variance were calculated revealing that respondents agreed in their positive evaluation of the payment concept. The index of neutrality, as a control index, confirmed that (see Table 4).

Insert Table 4 about here

Following the correspondence analysis methodology, the free associations from part one of the questionnaire (see Table 3) were used for more comprehensive frequency analyses. According to Abric (1993), words which were mentioned most frequently and appeared at the beginning in the association process, could be considered elements of the central nucleus (Abric, 1996b). This follows Zipf's law of word frequency distribution (see for example Baayen, 2001; Depken, 2008; Nitsch, 2005; Popescu, Altmann, and Köhler, 2010; Zipf, 1935, 1949). Using information on residence, gender, and education of respondents revealed only slight differences in the organization of social representations. This again confirms that natural groups based on common representations rather than based on socio-demographic information should be identified.

In the context of our study the central nucleus comprised cash, which appeared 58 times and money (frequency of 57). These two concepts represented the stable and normative part of the social representation towards payment systems and are essential elements. Cash represents the most familiar means of payment for people. In contrast to non-cash payment systems, it was seen as being tangible, the value is visible at first glance and national symbols are mapped on coins and banknotes. Money as the second element of the central nucleus itself is a 
social representation. Because people believe in the value and significance of money for society and trust in the monetary system, they have a desire for wealth and prestige (Moscovici, 2001; Vergès and Bastounis, 2001; Wagner, 1989).

We identified elements of the first periphery, which were characterized by a rank less than three and a frequency higher than eight. In the first periphery, traditional means of payment, e.g., Euro check, credit-card, ATM-card, but also coins and banknotes, and the currencies Euro and Austrian Schilling were found. These elements were more concrete than the elements of the central nucleus and described the group's typical payment systems. The concept of cash reappeared in the form of coins and banknotes, confirming its importance, while in addition also non-cash payment forms could be found: Euro check, credit-card, ATM-card. This controversy did not harm the stability of payment systems because it only occurred in the periphery. However, it showed that different groups or individuals diverged in their views of the payment concept. The same was true for the mentioned currencies. During data collection, the introduction of the Euro was discussed in the media and opinion polls were carried out to determine whether people were holding positive or negative views about the new European currency. Not surprisingly, these elements were also represented in our dataset; both the Austrian Schilling and the Euro were perceived as valid means of payment.

Finally, the second periphery comprised aspects such as telephone banking and the so called electronic purse, newer forms of payment and distribution channels. Following Abric's methodology, these elements were isolated from the central nucleus and thus did not (yet) form social representations. They are likely candidates to form part of the nucleus if their importance for the concept payment systems was strengthened.

The fourth step in our data analysis involved the application of similarity analysis in the context of a "conceptual network". Frequencies of graphically connected pairs of words were counted and analysed employing a similarity analysis (Barbry et al., 1996). The aim of 
similarity analysis is to simplify the similarity graph by stressing only those links between variables that are the most important ones. To this end, a so-called maximum tree, which consists of the highest possible number of pairs of variables is created. It displays the spatially strongest similarities between items and reflects the most important associations between them (Clemence, Lorenzi-Cioldi, and Doise, 1993; Degenne, 1985; Flament, 1985). Each of the graphs (see Figure 3 and Figure 4) represents the maximum number of connections between the items. The combination of variables can be read as (i) star-shaped structures which attach high importance to the element in the centre. The star-variable is used as a reference point for all connected variables. Another combination of variables is the (ii) triangle form, which according to Degenne (1985) and Vergès (1995) means that three connected variables share cognitive similarity.

Insert Figure 3 and Figure 4 about here

This methodology was applied to locate the structures of social representations and the strength of the associations between and within social and economic elements. Based on 25 concepts, which were chosen based on literature review and should reflect economic as well as social elements of everyday life (Vergès and Bastounis, 2001), their configuration in a social representations network was plotted. Figures 3 and 4 include all 25 concepts as words in circles or stars and show the maximum number of interconnections in the conceptualization of payment systems.

Splitting the dataset by sex-roles accounts for socially constructed groups (Baayen, 2001; Depken, 2008; Nitsch, 2005; Popescu et al., 2010), we were able to conclude that men perceived credit-cards to be wasteful and related to consumption, while women link creditcards to checks. Furthermore, women link cash to desires and self-worth (self-esteem), while 
men perceived cash as linked to work and control. This reflects existing sex roles in Western countries.

When contrasting the residential background (Figure 3 and Figure 4), we were able to identify even larger differences in the social representations of payment systems. People living in an urban environment linked credit-cards to debts and foreign-trade. Cash was connected to consumption, safety and control, while check was related to credit-cards. The rural population on the other hand linked the ATM-card to wastefulness and cash. Both groups shared some similarity regarding the ATM-card, the electronic purse and checks. Apart from this technical similarity, they perceived loss of control linked to the ATM- and the credit-card.

With regard to the newer payment modes, telephone-banking and internet-banking, only mistrust was connected with them.

While the cognitive patterns resembled the stereotypical configuration of the earlier correspondence analysis results, the interconnections and their interpretation helped to go beyond the understanding of the correspondence analysis. For instance, we could see that for the urban population the concept of cash was closely linked to safety and control. Cash was in the centre of a "star" pattern (Vergès, 1995), which implied that it was the most salient dimension. This also holds true for ATM-cards, credit-cards, and aspects like work and family. For each subsample, triangle shaped configurations were identified, thus indicating variables which were seen as highly similar (e.g., cash, safety and control in the urban sample and cash, work and desires in the rural sample).

\section{CONCLUSION AND IMPLICATIONS}

Marketing and social systems play a critical role in shaping consumers' views about innovations, and as can be seen from the present case of new means of payment, consumer adoption rates are not always as high as marketers would hope for. An adapted framework by 
Bauer and Gaskell (1999) and a four-step-approach were employed to obtain an empirically grounded understanding of consumers' socially-shared reasoning about new forms of payment.

The first step, objectification and anchoring, built on categorized free associations and correspondence analysis helped to configure response statements along two dimensions. On the one side responses pointed at an affective involvement of consumers regarding payment innovations and a "descriptive construction of reality". It was found that payment systems were related to dependence (e.g., "losing" security, dependence and independence, different payment systems, daily experience). The second step in the analysis was concerned with the evaluation of social representations and a generally positive view of means of payment was identified. Obviously everyone loves money and its derivatives. Step three involved core/periphery analysis. Positional and frequency analysis techniques were applied and "means of payment" were categorized into central and periphery positions. Core elements are normative for the group, i.e., group members agree on the importance of these. Overall, the concept of "means of payment" is largely determined by the understanding of money and cash. To achieve recognition from customers, marketers of new payment innovations should strive to link new means of payments to cash. As the data revealed, the peripheral area demonstrates less stability. The representations of banknotes and coins may change over time, differ in terms of appearance, and may also differ in terms of value. Peripheral dimensions are particularly relevant for managerial use in target marketing campaigns. They indicate "up and coming" areas of application and a certain openness from users. This highlights the importance of stressing those issues which help to link new means of payment to consumers' traditional perspectives of payments. It is, therefore, important to integrate informational cues which augment security, usability and trustworthiness into new means of payment, which are usually associated with traditional means of payments. Natural groups, characterized by rural and urban backgrounds or sex roles, demonstrated different perspectives regarding new means 
of payments, especially with respect to the configuration of underlying dimensions and components. This implies that innovation management will have to deliver group-specific marketing communication.

Step four pertained to the conceptual network analysis. The configuration and organization of social representations and the linkages between various pairs of concepts illustrated that while cash is seen as similar, conceptualizations of more abstract means of payment such as ATM or credit-cards differ. Links between means of payment and social life highlighted some interesting differences. In the urban context, cash is closely linked to control, while in the rural context it is linked to work and desires. The "family-cluster" also depicted some interesting differences. In the urban case, self-esteem derives from reputation and not work itself, while in the rural case, self-esteem derives from work. Credit-cards in the urban sample are linked to loss of control and debts (which is further linked to risk and wastefulness), while people in the rural area see credit-cards as a source of loss of control and the ATM, which is further linked to wastefulness.

Taken collectively, there is a strong argument for the use of the social representations theory, from a methodological as well as a managerial perspective. It offers useful sources of information for distinctive managerial decision making. In new product development, the results of social representations help to create an insight-stimulating body of knowledge. The feedback which is received from respondents is of an "idea-generating" nature and is directly relevant and applicable for decision making. In the context of this study, beneficial applications involve segmentation and targeting activities of banking institutions, and ATMcard issuers who can draw on the information in their creative execution, such as the design of products or the communication approach, including advertising. The results of this study point out that a focus on aspects such as security, trust and loss of control issues may help to successfully enhance current goods offerings. However, the social representations approach is 
not limited to tactical marketing decisions and is also suitable for strategic marketing problems. Specifically, in view of the growing importance of intercultural marketing, the social representations theory may also offer a theoretical framework for the analysis of similarities and dissimilarities of cross-cultural reference groups and highlight the importance of group influences across borders (Stewart and Lacassagne, 2005).

In terms of methodological contributions, the application of the social representations approach helped to enhance the interpretation of empirical data. Frequency analysis and the partitioning of the response-data into "central" and "peripheral" dimensions, augmented the initial understanding about means of payment. This was by uncovering aspects that could not have been traced by traditional segmentation and research methods based on attitudinal and perceptional analysis. Thus, the social representations approach has shown to be useful for the investigation of "deeper structure" aspects of consumer behaviour. The illustrative example, i.e., the concept of payment systems, was also studied within different social groups. The nature of the presented method suggests a stepwise advance, starting off with associations and following up with conceptualizing them in a network of similarities. The social representations methodology lends itself nicely to further applications in strategic and operational marketing contexts. The methodology is well suited to overcome a narrow, individualistic research focus and performs well in incorporating group-dimensions. To this end, the social representations theory may be very relevant for reference group/influencegroup studies.

The framework by Bauer and Gaskell (1999) supported the multi-step research project. However, in view of the flexibility of the social representations theory, some limitations of this study apply. Social representations of Austrian consumers regarding payment systems were assessed in a cross-sectional analysis. The social representations theory allows for more behavioural and process-oriented research and future research is encouraged to embrace this 
view by investigating informal and formal communication among group members. In addition, a longitudinal study might reveal further phenomena, which may be particularly pertinent with highly innovative products such as new payment systems (Montoya-Weiss and Calantone, 1994).

As shown in studies on decision makers' selection of new products and support decisions (Forlani and Walker Jr., 2003), much could be learned from past new product introductions and debriefing should take place to prepare decision makers for future new product introductions. Without doubt, the introduction of new payment methods comprises of a set of complex marketing decisions with uncertain outcomes, thus entailing potential pitfalls, which marketing decision makers are eager to avoid. As shown in the present study, "negative" outcomes include negative emotions with regard to new technology, and rather limited connection to existing payment options and everyday experiences.

Firms (banking institutions / merchants) also need to develop customer segmentation strategies. The practice of segmentation studies primarily involves the creation of taxonomic clusters (Bock and Uncles, 2002; Cestre and Darmon, 1998). These are mostly based on objectified criteria, such as demographic information, attitudinal profiles or consumption patterns (Wedel and Kamakura, 2000). From a managerial perspective, such segmentation exercises may fall short when it comes to new product developments, such as innovative financial goods. The rationale is that the tradition of forming consumer clusters ex post may, lead to self-referential units (nominal groups). In contrast, social and natural groups (i.e., milieus) usually have a "common project" or shared ideology (i.e., "Weltanschauung" according to Bauer and Gaskell, 1999), a collective memory and a common history. Following natural segmentation increases the likelihood of new product adoption. While the integration of these dimensions is quite difficult for traditional segmentation methodologies and designs, it is feasible in the social representations methodology. 
To this end, this paper suggests that researchers may consider adopting social representation theory for their research projects, specifically when social and group ideologies and perspectives are examined and future segments are to be formed rather than groupings based on past product adoption. Further research is thus encouraged, which builds on the benefits of social representations theory compared to other segmentation methods. With a view on the current interest in social media and social network tools, social representations theory also offers a plethora of benefits for research on market segmentation that is concerned with social groups, social exchange and perspectives of social constructivism. 


\section{REFERENCES}

Abrazhevich D. 2001. Classification and characteristics of electronic payment systems. In Bauknecht K, Madria SK, Pernul G (eds.). Ec-web 2001, lncs 2115. Springer: Berlin, Heidelberg; 81-90.

Abric J-C. 1993. Central system, peripheral system: Their functions and roles in the dynamics of social representations. Papers on Social Representations 2(2): 75-78.

Abric J-C. 1996a. De l'importance des répresentations sociales dans les problèmes de l'exclusion sociale. In Abric J-C (ed.). Exclusion sociale, insertion et prévention. Erès: Saint-Agne; 11-17.

Abric J-C. 1996b. Specific processes of social representations. Papers on Social Representations 5(1): 77-80.

Alba JW, Hutchinson JW. 1987. Dimensions of consumer expertise. Journal of Consumer Research 13(4): 411-454.

Armstrong JS, Overton TS. 1977. Estimating nonresponse bias in mail surveys. Journal of Marketing Research 14(3): 396-402.

Baayen RH. 2001. Word frequency distributions. Kluwer: Dordrecht u.a.

Bagozzi RP, Dholakia UM. 2006. Antecedents and purchase consequences of customer participation in small group brand communities. International Journal of Research in Marketing 23(1): 45-61.

Bagozzi RP, Gopinath M, Nyer PU. 1999. The role of emotions in marketing. Journal of the Academy of Marketing Science 27(2): 184-206.

Barbry W, Scano S, Vergès P, Zeliger R. (1996). Analyse de similitude (Version 1996). Aixen-Provence.

Bauer MW, Gaskell G. 1999. Towards a paradigm for research on social representations. Journal for the Theory of Social Behaviour 29(2): 163-186.

Bednar DA, Reeves CA, Lawrence RC. 1995. The role of technology in banking: Listen to the customer. Journal of Retail Banking 17(3): 35-41.

Belk RW, Wallendorf M. 1990. The sacred meanings of money. Journal of Economic Psychology 11(1): 35-67.

Benzécri J-P. 1992. Correspondence analysis handbook. Marcel Dekker: New York.

Bhattacharya CB, Sankar S. 2003. Consumer-company identification: A framework for understanding consumers' relationships with companies. Journal of Marketing 67(2): 76.

Blair ME, Innis DE. 1996. The effects of product knowledge on the evaluation of warranteed brands. Psychology and Marketing 13(5): 445-456.

Bock T, Uncles M. 2002. A taxonomy of differences between consumers for market segmentation. International Journal of Research in Marketing 19(3): 215-224.

Buchanan-Oliver M, Cruz A, Schroeder JE. 2010. Shaping the body and technology: Discursive implications for the strategic communication of technological brands. European Journal of Marketing 44(5): 635-652.

Cestre G, Darmon RY. 1998. Assessing consumer preferences in the context of new product diffusion. International Journal of Research in Marketing 15(2): 123-135.

Clemence A, Lorenzi-Cioldi F, Doise W. 1993. The quantitative analysis of social representations. Harvester Wheatsheaf: London.

Cordell VV. 1997. Consumer knowledge measures as predictors in product evaluation. Psychology and Marketing 14(3): 241-260.

Cova B. 1997. Community and consumption: Towards a definition of the "linking value" of product or services. European Journal of Marketing 31(3,4): 297-316. 
Cova B, Cova V. 2002. Tribal marketing: The tribalisation of society and its impact on the conduct of marketing. European Journal of Marketing 36(5/6): 595-620.

Davis FD, Bagozzi RP, Warshaw PR. 1989. User acceptance of computer technology: A comparison of two theoretical models. Management Science 35(8): 982-1003.

de Rosa AS. 1994. From theory to metatheory in social representations: The lines of argument of a theoretical-methodological debate. Social Science Information 33(2): 273-304.

de Rosa AS. 1995. Le "réseau d'associations" comme méthode d'étude dans la recherche sur les représentations sociales. Cahiers Internationaux de Psychologie Sociale.

de Rosa AS, Kirchler E. 2001. Ambiguous images in advertising: An application of the associative network. In Roland-Lévy C, Kirchler E, Penz E, Gray C (eds.). Everyday representations of the economy. WUV-Verlag: Wien; 49-65.

Degenne A. 1985. Presentation de l'analyse de similitude. Informatique et Sciences Humaines 67(numero spécial sur l'analyse de similitude): 7-26.

Depken CA. 2008. Benford, Zipf and the blogosphere. Applied Economics Letters 15(9): 689692.

Doise W, Clemence A, Lorenzi-Cioldi F. 1993. The quantitative analysis of social representations. Harvester Wheatsheaf: Hertfordshire.

Eagly AH. 1987. Sex differences in social behavior: A social role interpretation. Lawrence Erlbaum: Hillsdale.

Elliott R. 1999. Symbolic meaning and postmodern consumer culture. In Brownlie D, Saren M, Wensley R, Whittington R (eds.). Rethinking marketing. Sage Publications: London; 112-125.

Farr RM. 1996. The roots of modern social psychology. Blackwell Publishers: Oxford.

Featherstone M. 1991. Consumer culture \& postmodernism. Sage Publications: London.

Flament C. 1963. Applications of graph theory to group structure. Prentice-Hall, Inc.: Englewood, N.J.

Flament C. 1985. L'analyse de similitude: Une technique pour les recherches sur les representations sociales. Informatique et Science Humaines: 41-57.

Flick U. 1996. Psychologie des technisierten alltags. Soziale konstruktion und repräsentation technischen wandels in verschiedenen kulturellen kontexten. Westdeutscher Verlag: Opladen.

Forgas JP. 1981. Social cognition: Perspectives on everyday understanding. Academic Press: London.

Forlani D, Walker Jr. OC. 2003. Valenced attributions and risk in new-product decisions: How why indicates what's next. Psychology \& Marketing 20(5): 395-432.

Fraser C. 1994. Attitudes, social representations and widespread beliefs. Papers on Social Representations 3(1): 13-25.

Furnham A, Argyle M. 1998. The psychology of money. Routledge: London.

Gaskell G, Smith P. 1985. An investigation of youths' attributions for unemployment and their political attitudes. Journal of Economic Psychology 6(1): 65-80.

Gatignon H, Robertson TS. 1991. Innovative decision processes. In Robertson TS, Kassarjian $\mathrm{HH}$ (eds.). Handbook of consumer behavior. Prentice-Hall: Englewood Cliffs, NJ; 316-348.

Gilbert GN. 2008. Researching social life (3rd ed.). Sage Publications: London.

Greenacre MJ. 1984. Theory and application of correspondence analysis. Academic Press: London.

Gregan-Paxton J, Hibbard JD, Brunel FF, Azar P. 2002. "So that's what that is": Examining the impact of analogy on consumers' knowledge development for really new products. Psychology \& Marketing 19(6): 533-550.

Gregan-Paxton J, John DR. 1997. Consumer learning by analogy: A model of internal knowledge transfer. Journal of Consumer Research 24(3): 266-284. 
Gregan-Paxton J, Moreau P. 2003. How do consumers transfer existing knowledge? A comparison of analogy and categorization effects. Journal of Consumer Psychology 13(4): 422-430.

Holbrook MB, Hirschman EC. 1982. The experiential aspects of consumption: Consumer fantasies, feelings, and fun. Journal of Consumer Research 9(2): 132-140.

Iacobucci D, Churchill GA. 2010. Marketing research: Methodological foundations (10th ed.). South-Western Cengage Learning: Mason, Ohio.

Jacobson E. (1990). Eftpos and the consumers. An ongoing norwegian case study. Lysaker: National Institute for Consumer Research.

Jansson J, Marell A, Nordlund A. 2011. Exploring consumer adoption of a high involvement eco-innovation using value-belief-norm theory. Journal of Consumer Behaviour 10(1): 51-60.

Jick TD. 1979. Mixing qualitative and quantitative methods: Triangulation in action. Administrative Science Quarterly 24(4): 602-611.

Joiner C. 1998. Concept mapping in marketing: A research tool for uncovering consumers' knowledge structure associations. Advances in Consumer Research 25: 311-322.

Katz ML, Shapiro C. 1986. Product compatibility choice in a market with technological progress. Oxford Economic Papers 38: 146-165.

Kirchler E, Maciejovsky B, Schneider F. 2003. Everyday representations of tax avoidance, tax evasion, and tax flight: Do legal differences matter? Journal of Economic Psychology 24(4): 525-553.

Kleinschmidt EJ, Cooper RG. 1991. The impact of product innovativeness on performance. Journal of Product Innovation Management 8(4): 240-251.

Lambert DM, Harrington TC. 1990. Measuring nonresponse bias in customer service mail surveys. Journal of Business Logistics 11(2): 5-25.

Lawson R. 2002. Consumer knowledge structures: Background issues and introduction. Psychology \& Marketing 19(6): 447-456.

Lawson R, Bhagat PS. 2002. The role of price knowledge in consumer product knowledge structures. Psychology \& Marketing 19(6): 551-568.

Leone L, Perugini M, Bagozzi RP. 2005. Emotions and decision making: Regulatory focus moderates the influence of anticipated emotions on action evaluations. Cognition and Emotion 19(8): 1175-1198.

Liebowitz SJ, Margolis SE. 1994. Network externality: An uncommon tragedy. The Journal of Economic Perspectives 8(2): 133-150.

Matiaske W, Dobrov I, Bronner R. 1994. Anwendung der korrespondenzanalyse in der imageforschung. Marketing Zeitschrift für Forschung und Praxis (ZFP) 16(1): 42-54.

Meier-Pesti K, Penz E. 2008. Sex or gender? Expanding the sex-based view by introducing masculinity and femininity as predictors of financial risk taking. Journal of Economic Psychology 29(2): 180-196.

Meier K, Kirchler E. 1998. Social representations of the euro in Austria. Journal of Economic Psychology 19(6): 755-774.

Melina A. 1998. Computer-assisted text analysis methodology in the social sciences. Zentrum für Umfragen, Methoden und Analysen (ZUMA): Mannheim, Germany.

Molesworth M, Suortfi J-P. 2002. Buying cars online: The adoption of the web for highinvolvement, high-cost purchases. Journal of Consumer Behaviour 2(2): 155-168.

Montoya-Weiss MM, Calantone R. 1994. Determinants of new product performance: A review and meta-analysis. Journal of Product Innovation Management 11(5): 397417.

Morgan DL, Schwalbe ML. 1990. Mind and self in society: Linking social structure and social cognition. Social Psychology Quarterly 53(2): 148-164. 
Moscovici S. 1961. La psychoanalyse: Son image et son public. Presses Universitaires de France: Paris.

Moscovici S. 1963. Attitudes and opinions. Annual Review of Psychology 14: 231-260.

Moscovici S. 1984. The phenomenon of social representations. In Farr R, Moscovici S (eds.). Social representations. Cambridge University Press: Cambridge; 3-69.

Moscovici S. 2001. Introduction. In Roland-Lévy C, Kirchler E, Penz E, Gray C (eds.). Everyday representations of the economy. WUV-Verlag: Wien; 9-18.

Mühlbacher S, Hofmann E, Kirchler E, Roland-Lévy C. 2009. Household decision making: Changes of female and male partners' roles? Psychology \& Economics 2(2): 17-37.

Nataraajan R, Bagozzi RP. 1999. The year 2000: Looking back. Psychology \& Marketing 16(8): 631-642.

Nentwich M, Peissl W, Pisjak P. 1993. Konsumentenkarten - Neue Technologien - Neue Probleme? (Vol. 9). Verlag der österreichischen Staatsdruckerei: Wien.

Nitsch V. 2005. Zipf zipped. Journal of Urban Economics 57(1): 86-100.

O'Loughlin D, Szmigin I. 2006. Emerging perspectives on customer relationships, interactions and loyalty in irish retail financial services. Journal of Consumer Behaviour 5(2): 117-129.

Penz E. 2006. Researching the socio-cultural context: Putting social representations theory into action. International Marketing Review 23(4): 418-437.

Penz E, Meier-Pesti K, Kirchler E. 2004. "It's practical, but no more controllable": Social representations of the electronic purse in Austria. Journal of Economic Psychology 25(6): 771-787.

Penz E, Stöttinger B. 2008. Original brands and counterfeit brands - Do they have anything in common? Journal of Consumer Behaviour, 7: 146-163.

Plouffe CR, Vandenbosch M, Hulland J. 2001. Intermediating technologies and multi-group adoption: A comparison of consumer and merchant adoption intentions toward a new electronic payment system. Journal of Product Innovation Management 18(2): 65-81.

Popescu I-I, Altmann G, Köhler R. 2010. Zipf's law - another view. Quality and Quantity 44(4): 713-731.

Prince M. 1993. Women, men and money stiles. Journal of Economic Psychology 14(1): 175182.

Rateau P, Moliner P, Guimelli C, Abric J-C. 2012. Social representation theory. In Lange PAMV, Kruglanski AW, Higgins ET (eds.). Handbook of theories of social psychology vol. 2. Sage: Los Angeles, California; 477-497.

Rogers EM. 1995. Diffusion of innovations (4th ed.). Free Press: New York, NY.

Roland-Lévy C. 1990. Economic socialization: Basis for international comparisons. Journal of Economic Psychology 11(4): 469-482.

Roland-Lévy C. 2001. Financial behavior of households and social representations. In Roland-Lévy C, Kirchler E, Penz E, Gray C (eds.). Everyday representations of the economy. WUV-Verlag: Wien; 67-91.

Roland-Lévy C, Boumelki F-EP, Guillet E. 2010. Representation of the financial crisis. Effect on social representations of savings and credit. The Journal of Socio-Economics, 39; 12-149.

Rosa JA, Porac JF, Runser-Spanjol J, Saxon MS. 1999. Sociocognitive dynamics in a product market. Journal of Marketing 63: 64-77.

Roy DP, Cornwell TB. 2004. The effects of consumer knowledge on responses to event sponsorships. Psychology \& Marketing 21(3): 185-207.

Scandura TA, Williams EA. 2000. Research methodology in management: Current practices, trends, and implications for future research. Academy of Management Journal 43(6): 1248-1264. 
Stewart I, Lacassagne M-F. 2005. Social representations as a diagnostic tool for identifying cultural and other group differences. Psychology \& Marketing 22(9): 721-738.

Timmor Y, Katz-Navon T. 2008. Being the same and different: A model explaining new product adoption. Journal of Consumer Behaviour 7(3): 249-262.

Vergès P. 1987. A social cognitive approach to economic representations. In Doise W, Moscovici S (eds.). Current issues in european social psychology (Vol. 2). Cambridge University Press: Cambridge; 271-304.

Vergès P. 1995. Représentations sociales partagées, périphériques, indifférentes, d'une minorité: Méthodes d'approche. Les Cahiers Internationaux de Psychologie Sociale (28): 77-95.

Vergès P. (1996, September 11-15). A method of analysis by questionnaires to know social representations of the economy. Paper presented at the IAREP, Paris, France.

Vergès P, Bastounis M. 2001. Towards the investigation of social representations of the economy: Research methods and techniques. In Roland-Lévy C, Kirchler E, Penz E, Gray C (eds.). Everyday representations of the economy. WUV-Verlag: Wien; 19-48.

Vergès P, Flament C. 1997. Comparaison de methode: A propos de l'article "apport des modeles graphiques gaussiens en analyse de similitude". Papers on Social Representations 6(1): 73-87.

Wagner W. 1989. Social representation and beyond: Brute facts, symbolic coping and domesticated worlds. Culture \& Psychology 4(3): 297-329.

Wagner W, Duveen G, Farr R, Jovchelovitch S, Lorenzi-Cioldi F, Marková I, Rose D. 1999. Theory and method of social representations. Asian Journal of Social Psychology 2: 95-125.

Wang C-C, Lo S-K, Fang W. 2008. Extending the technology acceptance model to mobile telecommunication innovation: The existence of network externalities. Journal of Consumer Behaviour 7(2): 101-110.

Wedel M, Kamakura WA. 2000. Market segmentation - conceptual and methodological foundations (2nd ed.). Kluwer: Boston.

Zipf GK. 1935. The psychobiology of language, an introduction to dynamic philology. Houghton-Mifflin: Boston.

Zipf GK. 1949. Human behaviour and the principle of least effort : An introduction to human ecology. Addison-Wesley Press: Cambridge, Mass. 
Table 1: Sample characteristics - descriptive information

\begin{tabular}{lrr}
\hline Gender & Frequency $(N)$ & Percent $(\%)$ \\
$\quad$ Male & 91 & $52.6 \%$ \\
Female & 82 & $47.4 \%$ \\
Age & & \\
$15-19$ Yrs & 17 & $9.8 \%$ \\
$20-29$ Yrs & 58 & $33.5 \%$ \\
$30-39$ Yrs & 34 & $19.7 \%$ \\
40-49 Yrs & 26 & $15.0 \%$ \\
50-65 Yrs & 36 & $20.8 \%$ \\
Marital status & & \\
Married & 69 & $39.9 \%$ \\
Long-term relationship & 16 & $9.2 \%$ \\
Single & 75 & $43.4 \%$ \\
Divorced & 7 & $4.0 \%$ \\
$\quad$ Widowed & 6 & $3.5 \%$ \\
Education & & \\
Primary/secondary school & 53 & $30.8 \%$ \\
$\quad$ Vocational middle school & 17 & $9.9 \%$ \\
$\quad$ Vocational higher school & 17 & $9.9 \%$ \\
Vocational training & 51 & $29.7 \%$ \\
High school & 25 & $14.5 \%$ \\
University/college & 9 & $5.2 \%$ \\
City / rural area & & \\
City & 114 & $66.3 \%$ \\
Rural area & 58 & $33.7 \%$
\end{tabular}


Table 2: Analytic design - Procedures of data analysis and interpretation

\begin{tabular}{|c|c|}
\hline Steps & Illustration \\
\hline $\begin{array}{l}\text { Step 1: } \\
\text { Objectification and } \\
\text { anchoring }\end{array}$ & $\begin{array}{l}\text { - Input data and method: Associative network (part one of the } \\
\text { questionnaire, free associations) } \\
\text { - Purpose: Objectification and anchoring, social content } \\
\text { - Technique: Correspondence analysis (Benzécri, 1992; Greenacre, } \\
\text { 1984) } \\
\text { - Result: Categorization of qualitative aspects, structural configuration } \\
\text { of response categories and respondents }\end{array}$ \\
\hline $\begin{array}{l}\text { Step 2: } \\
\text { Evaluation of } \\
\text { object }\end{array}$ & $\begin{array}{l}\text { - Input data and method: Associative network (part one of the } \\
\text { measurement tool, free associations) } \\
\text { - Purpose: Evaluative components of social representations } \\
\text { - Technique: Index of polarity and neutrality (de Rosa, 1995; de Rosa } \\
\text { - } \text { and Kirchler, 2001) } \\
\text { Result: Extent of polarity and neutrality of the payment concept }\end{array}$ \\
\hline $\begin{array}{l}\text { Step 3: } \\
\text { Configuration - } \\
\text { Importance }\end{array}$ & $\begin{array}{l}\text { - Input data and method: Associative network (part one of the } \\
\text { questionnaire, free associations) } \\
\text { - Purpose: Configuration of social representations, importance of } \\
\text { elements of the payment systems } \\
\text { - Technique: Positional and frequency analysis (Zipf, 1935) } \\
\text { - Result: Categorization of elements into central nucleus and periphery } \\
\text { of "means of payment" }\end{array}$ \\
\hline $\begin{array}{l}\text { Step 4: } \\
\text { Configuration - } \\
\text { Linkage }\end{array}$ & $\begin{array}{l}\text { - Input data and method: Conceptual network method (part two of the } \\
\text { questionnaire) } \\
\text { - Purpose: Configuration of social representations, linkage between } \\
\text { pairs of concepts, and the socio-economic environment. } \\
\text { - Technique: Similarity analysis (Barbry et al., 1996; Degenne, 1985; } \\
\text { Flament, 1963) } \\
\text { - Result: Organization of social representations }\end{array}$ \\
\hline
\end{tabular}


Table 3: Frequencies of the categories for stimulus 'payment systems' and examples of typical associations

\begin{tabular}{|c|c|c|c|c|c|c|c|c|c|c|c|c|c|c|}
\hline & & \multicolumn{7}{|c|}{ Education } & \multicolumn{3}{|c|}{ Residence } & \multicolumn{3}{|c|}{ Gender } \\
\hline & & E1 & E2 & E3 & E4 & E5 & E6 & $\Sigma$ & $\bar{U}$ & $\mathrm{R}$ & $\Sigma$ & M & $\mathrm{F}$ & $\Sigma$ \\
\hline 1 & $\begin{array}{l}\text { Payment forms (e.g., coins, cards, } \\
\text { bank bill): includes every form of } \\
\text { payment }\end{array}$ & 52 & 17 & 16 & 48 & 24 & 9 & 166 & 89 & 77 & 166 & 86 & 81 & 167 \\
\hline 2 & $\begin{array}{l}\text { Currencies (e.g., ATS, Euro, German } \\
\text { mark): includes names of all } \\
\text { mentioned currencies }\end{array}$ & 28 & 4 & 8 & 27 & 13 & 5 & 85 & 44 & 41 & 85 & 47 & 38 & 85 \\
\hline 3 & $\begin{array}{l}\text { Dealing with means of payment (e.g., } \\
\text { withdrawing cash, paying, } \\
\text { bargaining): refers to activities and } \\
\text { processes that customers, merchants } \\
\text { and bank institutions apply when } \\
\text { dealing with payments }\end{array}$ & 34 & 9 & 11 & 23 & 11 & 6 & 94 & 50 & 44 & 94 & 45 & 50 & 95 \\
\hline 4 & $\begin{array}{l}\text { Synonyms (e.g., alike cash, "Zaster", } \\
\text { "Kies", "Kröten"): captures terms } \\
\text { that people use to express payment } \\
\text { forms and money }\end{array}$ & 2 & 0 & 0 & 3 & 3 & 0 & 8 & 7 & 1 & 8 & 5 & 3 & 8 \\
\hline 5 & $\begin{array}{l}\text { Characteristics of payment forms } \\
\text { (e.g., PIN-Code, signature, plastic): } \\
\text { refers to any aspect and elements that } \\
\text { characterize payment forms }\end{array}$ & 3 & 1 & 1 & 4 & 3 & 3 & 15 & 7 & 8 & 15 & 9 & 6 & 15 \\
\hline 6 & $\begin{array}{l}\text { Piece of equipment (e.g., purse, } \\
\text { check-book, piggybank, pen): include } \\
\text { elements that are part of using certain } \\
\text { payment forms }\end{array}$ & 22 & 5 & 8 & 16 & 5 & 5 & 61 & 25 & 37 & 62 & 30 & 32 & 62 \\
\hline 7 & $\begin{array}{l}\text { Advertising (e.g., "Veni-vidi-Visa", } \\
\text { Mr. Quick): includes slogans, } \\
\text { pictures, symbols or brands of } \\
\text { advertising campaigns on payment } \\
\text { forms }\end{array}$ & 2 & 1 & 1 & 1 & 1 & 0 & 6 & 2 & 4 & 6 & 2 & 4 & 6 \\
\hline 8 & $\begin{array}{l}\text { Banking World (e.g., rate of } \\
\text { exchange, counter, rate, bank } \\
\text { employee): refers to elements that are } \\
\text { idiosyncratic to financial institutions }\end{array}$ & 19 & 4 & 4 & 15 & 4 & 4 & 50 & 20 & 29 & 49 & 26 & 24 & 50 \\
\hline 9 & $\begin{array}{l}\text { Earning money (e.g. work, pocket } \\
\text { money, salary): includes activities } \\
\text { and elements that lead to positive } \\
\text { financial outcome }\end{array}$ & 10 & 3 & 3 & 6 & 2 & 1 & 25 & 14 & 11 & 25 & 15 & 11 & 26 \\
\hline 10 & $\begin{array}{l}\text { Spending money (e.g., holidays, } \\
\text { purchasing, tip): includes activities } \\
\text { and elements money is spent on }\end{array}$ & 20 & 7 & 4 & ce & 7 & 4 & 54 & 26 & 28 & 54 & 30 & 25 & 55 \\
\hline 11 & $\begin{array}{l}\text { Charge, fee (e.g., expensive, costs, } \\
\text { check-fee): refers to extra costs that } \\
\text { arise in financial transactions }\end{array}$ & 4 & 1 & 3 & 7 & 3 & 2 & 20 & 9 & 10 & 19 & 12 & 8 & 20 \\
\hline 12 & $\begin{array}{l}\text { Financial advantages (e.g., insurance } \\
\text { protection, additional service, cost- } \\
\text { effective): include instances that } \\
\text { people link to financial earnings }\end{array}$ & 1 & 0 & 1 & 0 & 1 & 1 & 4 & 2 & 2 & 4 & 0 & 4 & 4 \\
\hline 13 & $\begin{array}{l}\text { Safety, trust (e.g., low risk, safe, trust, } \\
\text { insurance): include elements and } \\
\text { concepts that make people feel safe } \\
\text { and trustful }\end{array}$ & 1 & 2 & 0 & 2 & 0 & 0 & 5 & 3 & 2 & 5 & 2 & 3 & 5 \\
\hline 14 & $\begin{array}{l}\text { Loss (e.g., theft, fraud, misuse, bank } \\
\text { robbery): refers to any financial crisis } \\
\text { due to loss of money }\end{array}$ & 2 & 2 & 0 & 2 & 2 & 0 & 8 & 4 & 4 & 8 & 2 & 6 & 8 \\
\hline 15 & $\begin{array}{l}\text { Wealth (e.g., Scrooge, luxury, } \\
\text { prosperity): refers to any gain of } \\
\text { money }\end{array}$ & 6 & 3 & 3 & 4 & 2 & 2 & 20 & 11 & 8 & 19 & 9 & 11 & 20 \\
\hline 16 & $\begin{array}{l}\text { Poverty (e.g., overextended account, } \\
\text { bust, beggar): includes elements and }\end{array}$ & 3 & 1 & 1 & 3 & 2 & 1 & 11 & 8 & 2 & 10 & 5 & 6 & 11 \\
\hline
\end{tabular}




\begin{tabular}{|c|c|c|c|c|c|c|c|c|c|c|c|c|c|c|}
\hline & activities that lead to a negative state & & & & & & & & & & & & & \\
\hline 17 & $\begin{array}{l}\text { Freedom (e.g., fun, independence): } \\
\text { expresses aspects that are related to } \\
\text { the value }\end{array}$ & 0 & 0 & 0 & 2 & 1 & 0 & 3 & 1 & 2 & 3 & 2 & 1 & 3 \\
\hline 18 & $\begin{array}{l}\text { General positive expressions (e.g., } \\
\text { comfortable, super, good): includes } \\
\text { general positive connotations }\end{array}$ & 2 & 1 & 1 & 3 & 4 & 0 & 11 & 6 & 5 & 11 & 6 & 5 & 11 \\
\hline 19 & $\begin{array}{l}\text { General negative expressions (e.g., } \\
\text { inconvenient, showing off, bad, } \\
\text { ridiculous): includes general negative } \\
\text { connotations }\end{array}$ & 1 & 0 & 1 & 5 & 1 & 0 & 8 & 5 & 3 & 8 & 4 & 4 & 8 \\
\hline & Total & 212 & 61 & 66 & 183 & 89 & 43 & 654 & 333 & 318 & 651 & 337 & 322 & 659 \\
\hline
\end{tabular}

Note: $\quad$ E1=primary/secondary school, E2=vocational middle school, E3=vocational high school, E4=vocational training, $E 5=$ high school, E6=university/college degree; $U=$ urban residence, $R=$ rural residence; $M=$ Male, $F=F e m a l e$ 
Table 4: Means and standard deviations for the indexes of polarity and neutrality

\begin{tabular}{|c|c|c|c|c|}
\hline & \multicolumn{2}{|c|}{ Index of Polarity ${ }^{a}$} & \multicolumn{2}{|c|}{ Index of Neutrality } \\
\hline & M & $\mathrm{SD}$ & M & SD \\
\hline Payment Systems & .28 & .32 & .32 & .21 \\
\hline
\end{tabular}


Figure 1: Obtaining the meaning of payment systems through the analysis of social representations

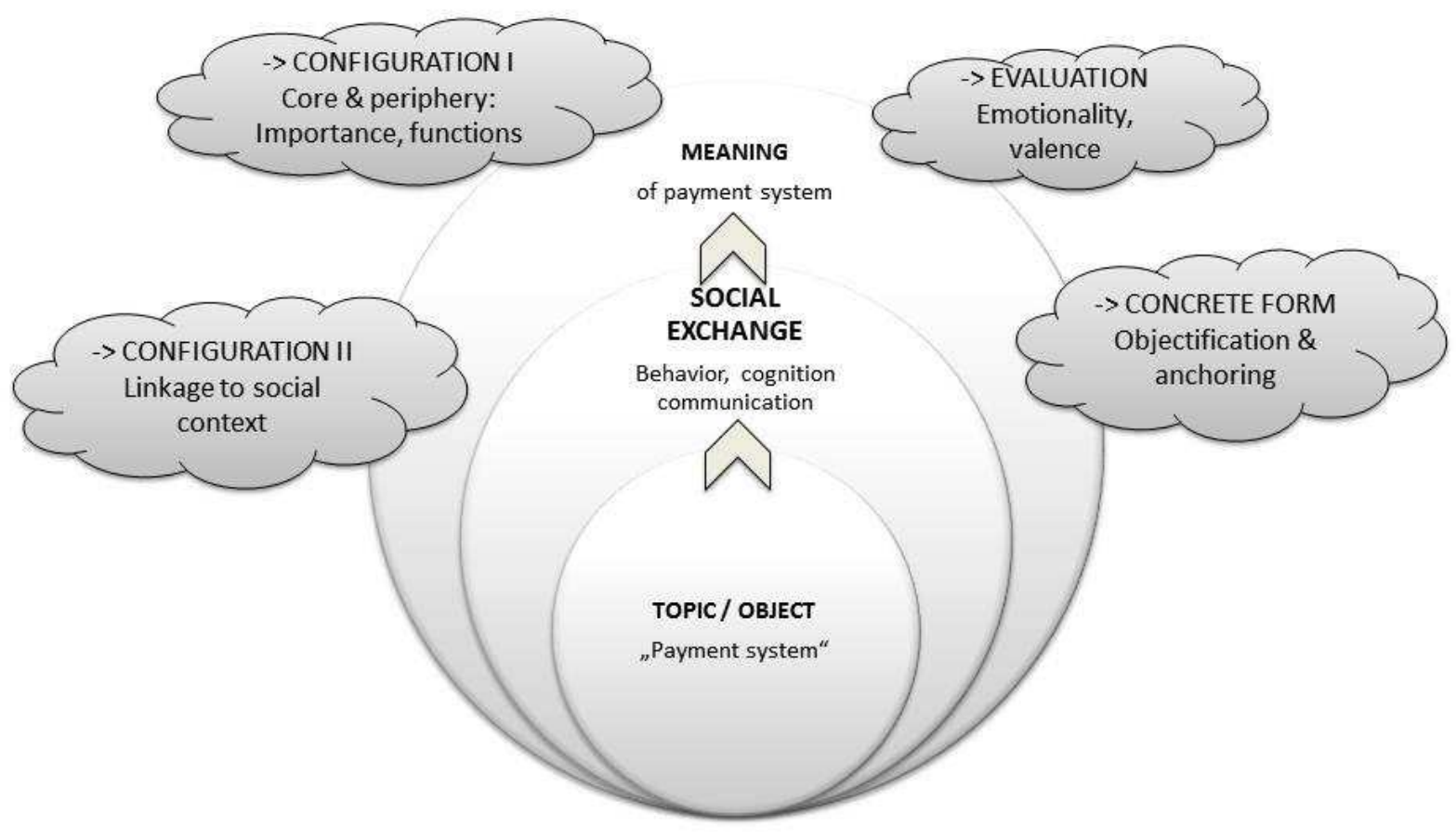


Figure 2: Graphical portrayal of correspondence analysis results

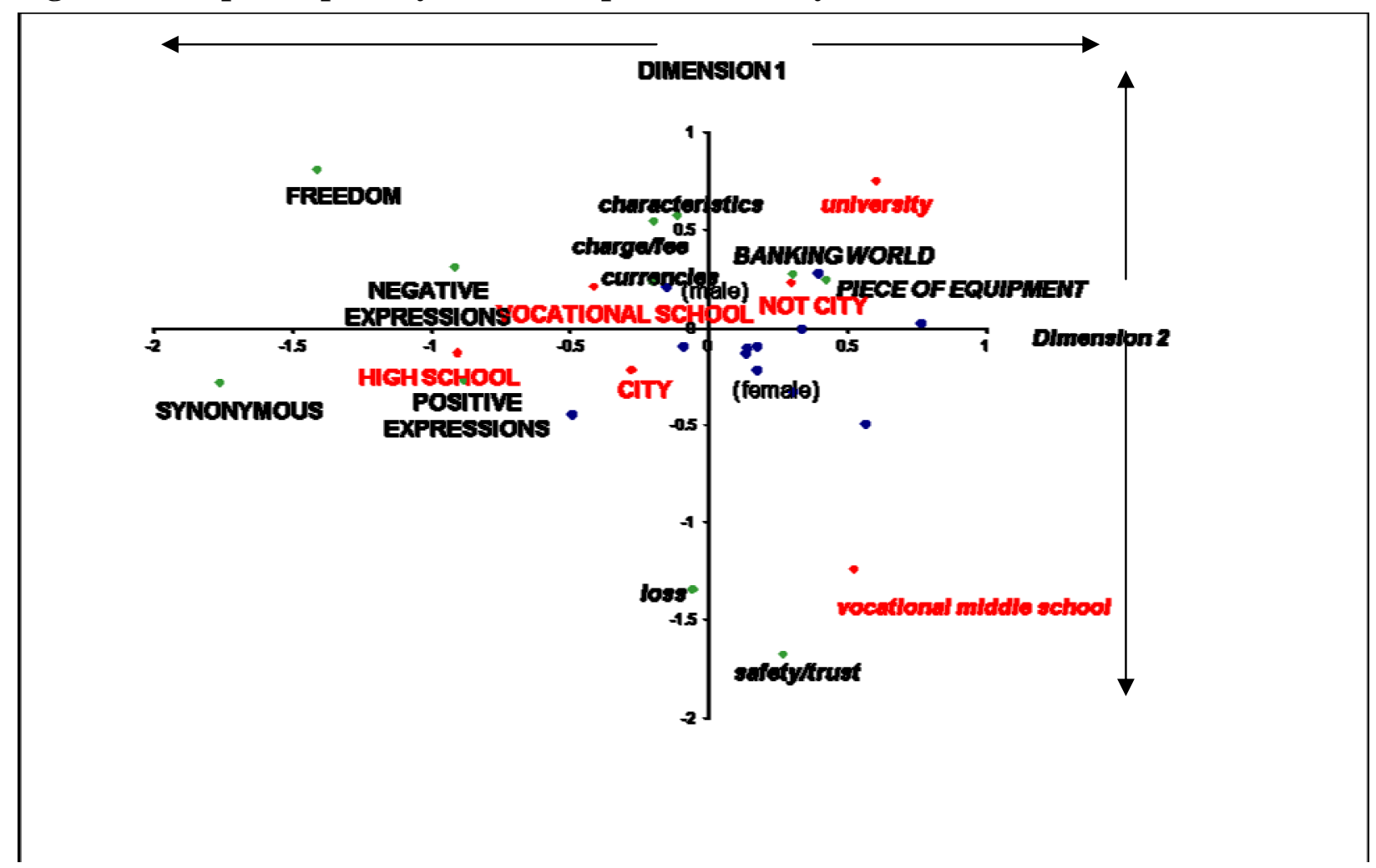

Note: Categories, which contribute significantly to one of the dimensions, are displayed. Points without description do not contribute significantly to the correspondence-solution. Categories in capital letters relate to dimension 1.

Categories in Italics refer to dimension 2. Capital letters and italics indicate that the respective categories contribute to both dimensions. 
Figure 3: Conceptual network representations of payment innovations - urban sample

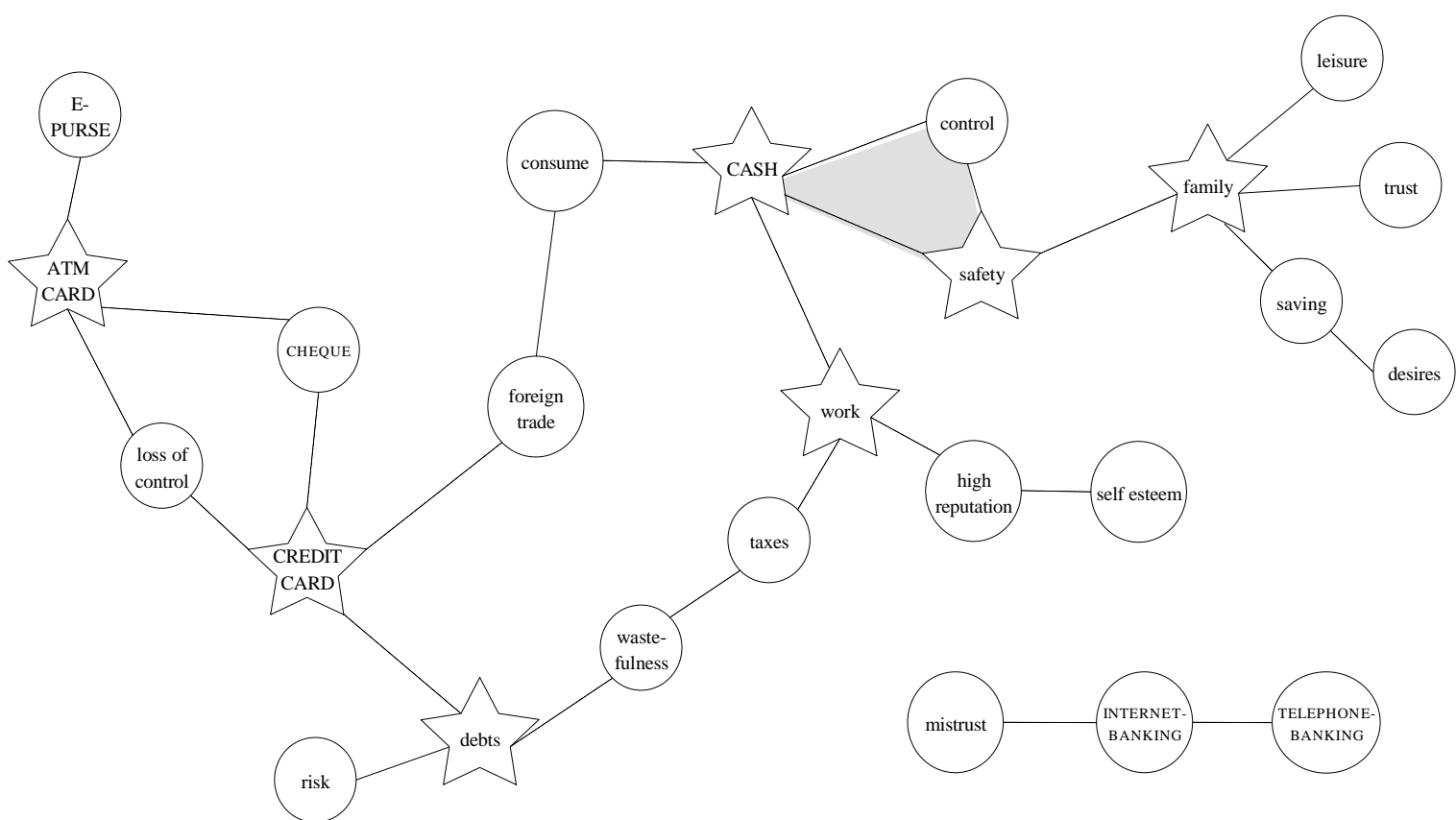

Note: star (reference point for connected variables), $\nabla$ triangle (variables are perceived as similar), O (element of conceptual network), connections between variables are based on similarity index, .... 13-25\% of respondents, - 26$50 \%$ of respondents, $-51-75 \%$ of respondents 
Figure 4: Conceptual network representations of payment innovations - rural sample

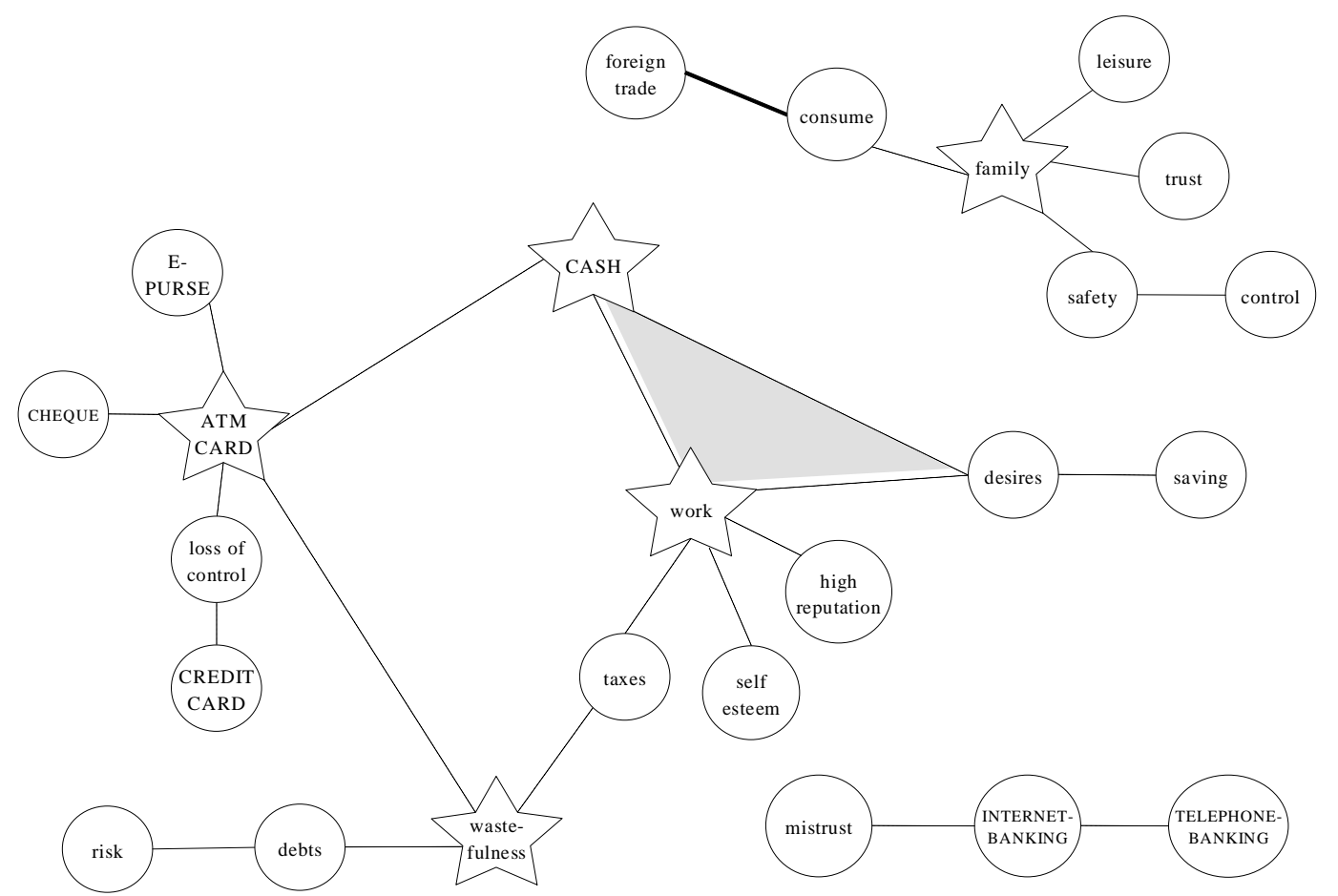

Note: star (reference point for connected variables), Dtriangle (variables are perceived as similar), $\bigcirc$ (element of conceptual network), connections between variables are based on similarity index, .... 13-25\% of respondents, - 26$50 \%$ of respondents, $-51-75 \%$ of respondents 